\title{
Development of Fiber Rich Soft Dough Biscuits Fortified with Kohila (Lasia spinosa) Flour
}

Pupulawaththa AW ${ }^{1}$, Perera ODAN ${ }^{1 *}$ and Ranwala $A^{2}$

${ }^{1}$ Department of Food Science and Technology, Faculty of Livestock Fisheries and Nutrition, Wayamba University of Sri Lanka, Makandura, Gonawila (NWP), Sri Lanka ${ }^{2}$ CBL Food International (Pvt) Ltd., Ranala, Sri Lanka

\begin{abstract}
Currently there is a growing demand for fiber fortified food products in the world to prevent from non-communicable diseases. To develop high fiber soft dough biscuit, kohila flour was added to biscuit formulation at $10 \%$ and $15 \%$ levels (w/w), respectively. Sugar was substituted with sucralose $(1 \mathrm{~g})$ to obtain a low energy product. The chemical and proximate compositions of the product (moisture, $\mathrm{pH}$, protein, fat, ash, dietary fiber, carbohydrate, sodium and heavy metal, antioxidant capacity) were determined. Sensory evaluation was carried out by a panel of thirty semi trained panelists, using a paired preference test and hedonic test to select the most preferred sample with the best sensory attributes. A market survey was done by using sixty sample sizes to evaluate the consumer preference for the prepared biscuit. Results showed that kohila flour fortified biscuits contained significantly $(\mathrm{p}<0.05)$ high amount of fiber $(7 \%(\mathrm{w} / \mathrm{w})$, on dry basis). High amount of iron $(48 \% \mathrm{ppm}$, dry basis) contained in fortified biscuits while none of the toxic heavy metals ( $\mathrm{As}, \mathrm{Pb}$ and $\mathrm{Cd}$ ) were absent. The antioxidant capacity (Radical DPHH scavenging capacity) was as high in kohila flour added biscuits (20-23\%). The $10 \%$ kohila flour added biscuits yielded the highest consumer acceptability. Survey results showed that there was a correlation between preference for sucralose added biscuits and health condition $(p<0.05)$ of the consumers. The preference for fiber fortified biscuits and sucralose added biscuit were high in consumers with higher level of education. Findings of this study revealed that $10 \%$ kohila flour fortified biscuits can be used as a rich source of dietary fiber which was beneficial to improve the health of the consumers.
\end{abstract}

Keywords: Non communicable diseases; Soft dough biscuits; Dietary fiber; Consumers; Antioxidant

\section{Introduction}

Non communicable diseases (NCDs), together with injuries and violence, are now causing about $60 \%$ deaths worldwide. In all regions of the world, except in Sub-Sahara Africa, NCDs are the leading cause of deaths and majority of world's NCDs deaths occurs in the economically developing countries $[1,2]$. Strong evidence shows that an unhealthy diet and insufficient physical activity are among major causal factors in NCDs such as coronary heart diseases, ceribrovascular strokes, several forms of cancers, type 2 diabetes, hypertension, obesity, osteoporosis, dental caries and other conditions, Such unhealthy diets include high amount of salt, fat, sugar and less dietary fiber (DF).

Dietary fiber is a member of a family of dietary complex carbohydrates which resistant to digestion and absorption in the human small intestine [3-5]. Dietary fiber has a protective action against various health disorders such as diabetes mellitus, cardiovascular diseases, constipation, appendicitis, hemorrhoids, and colon cancer $[6,7]$. Fruits, vegetable, cereals (especially in outer layer) and seaweeds are rich in dietary fiber. Recommended dietary allowance of DF for an adult is $20-35 \mathrm{~g} /$ day and it should be fulfilled from the food to maintain a healthy life [8]. In recent years, there has been increasing interest in the use of natural food additives and incorporation of health promoting substances into the diet as dietary fiber [9].

A study has found that Lasia spinosa (Sri Lankan name: Kohila) is a good source of dietary fiber that helps to control dietary related diseases like cancer, cardiovascular conditions and diabetics [10]. The rhizome of Lasia spinosa is a rich source of dietary fiber with $40-75 \%$ of total dietary fiber on dry weight basis, (7.2-7.5\% on fresh weight basis) constituting $35-60 \%$ and $4-18 \%$ of insoluble and soluble fiber [11]. Kohila is good for diabetic sufferers and those with high cholesterol because of its tendency to reduce absorption of sugar and fats. Kohila rhizome possesses a wide-ranging antioxidant capacity. The contribution of polyphenols to the antioxidant activity is range from
$14-48 \%$. In addition to polyphenols, ascorbic acid also contributes to the total antioxidant activity (34-56\%). The antioxidants can act independently or synergistically with fiber, since Kohila is a rich source of dietary fiber to reduce the adverse effects of various diseases as cancers [12]. Due to the high prevalence of fiber, it gives a good motion. Kohila reduces unnecessary toxins in the intestines and is effective for other disorders in the intestines [13] which also help to get rid from colon cancers. Thus Kohila rhizome can be considered as a valuable functional food from the view point of its antioxidant and dietary fiber content.

Kohila is a spinous marshy herb which grows in wet zone of Sri Lanka, mainly in swamps, riverbanks, ditches, moist places in tropical and subtropical forests [14]. Kohila plant can be found abundantly in local market all throughout the year [15]. Today most people go for convenience food. Therefore many people don't like to eat Kohila as a vegetable due to its inconvenience and bulky nature. Although Kohila is consider of as a valuable herb and food worldwide, only few numbers of studies have been conducted regarding Kohila and Kohila based food products.

Biscuits are considered as the most popular bakery products worldwide and generally accepted by all age groups, due to its characters such as convenience, good taste, cheap and conventional nature.

*Corresonding author: Perera ODAN, Department of Food Science and Technology, Faculty of Livestock Fisheries and Nutrition, Wayamba University of Sri Lanka, Makandura, Gonawila (NWP), Sri Lanka, E-mail: aannpp2003@yahoo. co.uk

Received October 15, 2014; Accepted October 29, 2014; Published November 06, 2014

Citation: Pupulawaththa AW, Perera ODAN, Ranwala A (2014) Development of Fibe Rich Soft Dough Biscuits Fortified with Kohila (Lasia spinosa) Flour. J Food Process Technol 5: 395. doi:10.4172/2157-7110.1000395

Copyright: (C) 2014 Pupulawaththa AW, et al. This is an open-access article distributed under the terms of the Creative Commons Attribution License, which permits unrestricted use, distribution, and reproduction in any medium, provided the original author and source are credited. 
Biscuits are classified as hard dough biscuits and soft dough biscuits which is relevant to the gluten formation when dough mixing [16]. The fortification of biscuits with different kinds of nutrients is a common trend [17]. Therefore development of fiber rich biscuits using Kohila powder will be a suitable vehicle for dietary fiber supplement for the modern meal. Under this study preparation of Kohila biscuit is done as a soft dough biscuit, using rhizomes because of the high nutritional value, easiness of the getting considerable amount of powder from rhizomes rather than other parts of the Kohila plant.

The objectives of the study were,

- To identify the potential of Kohila flour in development of fiber rich biscuits,

- To determine the antioxidant capacity of Kohila biscuits,

- To determine the sensory quality of Kohila biscuits,

- To determine the shelf life of Kohila biscuits and to determine the consumer preference

\section{Materials and Methods}

This project was conducted at the Quality Assurance (QA) Laboratory of Ceylon Biscuits Ltd (Ranala) under the supervision of the Quality Assurance Executives and at the preservation and chemical laboratories of Wayamba University Sri Lanka.

Kohila rhizome in the premature stage, were purchased from a local market. The Kohila were washed, peels were removed and cut into small pieces. The pieces were then oven dried at $60^{\circ} \mathrm{C}$ for $48 \mathrm{~h}$, and ground with a commercial grinder into $250 \mu \mathrm{m}$ mesh size, vacuum packed in airtight polypropylene plastic containers and stored at $\left(4^{\circ} \mathrm{C}\right)$ under refrigerated condition.

Flour mixer was prepared by mixing wheat flour and Kohila powder at low speed $(60 \mathrm{rpm})$. Sugar, palm oil and whey powder were mixed in a mixer for $30 \mathrm{~s}$ at low speed $(30 \mathrm{rpm})$. Ammonium hydrogen carbonate (previously dissolved in small amount of water), was added in to the mixer and sodium bicarbonate and salt (previously dissolved in small amount of water), were added into the mixer and mixed 5 min at a high speed $(40 \mathrm{rpm})$ by adding water little by little. Flour mixer was added (previously prepared) and was mixed for a further $3 \mathrm{~min}$ at a low speed $(30 \mathrm{rpm})$. Finally dough was rolled by feeding roller and embossed in to square shaped cutters $(41 \mathrm{~mm}$ in length and width and $5 \mathrm{~mm}$ in height). Then square pieces (41 $\mathrm{mm}$ in length and width) were taken to a rough canvas due to higher affinity of the canvas. After passing through this rotary molding machine, biscuits were baked in an indirect cyclothermic oven in a five sections for $6.15 \mathrm{~min}$. The temperature of the oven in each sample was about $230-280^{\circ} \mathrm{F}$. After cooling to ambient temperature, the biscuits were packed and stored in heat-sealed metalized polypropylene bags.

Four samples were prepared. The percentages of the biscuit formulations are shown in Table 1. The code letters for the samples were C (control, complete formulation), A and B (respectively 10\% and $15 \%$ added Kohila powder replacing wheat flour), and D (added sucralose).

C: control (without Kohila flour); A: 10\% added Kohila flour; B: 15\% added Kohila flour;D: 10\% added kohila flour and suralose.

Protein, fat, ash, dietary fiber, carbohydrate, sodium and heavy metal (Al, Be, Cu, Fe, Ni, Zn, Cd, Cr, Mo, Pb, Sb, As and Se), antioxidant contents were analyzed using Kjeldahl method, Soxhlet method,
Gravimetric method, AOAC 985.29:1988 method, By difference method, AOAC 944.02-32.1.09 Method, Spectrometry method, and DPPH methods, respectively. Moisture content was determined by oven drying method and $\mathrm{pH}$ determination was carried out using a $\mathrm{pH}$ meter ( $\mathrm{pH}$ range: $0.00 \mathrm{pH}$ to $14.0 \mathrm{pH}$, Resolution: $0.01 \mathrm{pH}$, Relative Accuracy: $\pm 0.01 \mathrm{pH}$ ). Bomb calorimeter method (1341 plain jacket bomb calorimeter) was used to determine the energy content of samples.

Thirty semi trained panelists carried sensory evaluation of Kohilasoft dough biscuits samples. Fifteen minutes preliminary sessions were conducted to train the panelists so as to familiarize themselves with the samples. After the session, the panelists were able to understand the test and were given a score sheet to select the most preferred sample from the sample A and B. In the second sensory score sheets were given to evaluate sensory attributes of four samples (C, A, B, D) namely, color, taste, smell, crispiness, overall texture (OAT), and asked to score samples on 7-point scale where scores 1, 2, 3, 4, 5, 6, and 7 represented extremely dislike, moderately dislike, slightly dislike, neither like nor dislike, slightly like, moderately like and extremely like respectively.

For the six months shelf life evaluation the moisture, $\mathrm{pH}$ and peroxide value of the samples were measured at two weeks intervals, total plate count was measured monthly at intervals and check whether those values were within the relevant range. Microbial analysis as Total plate count (SLS 516 part 1:1991), Coliform, Escherichia coli (SLS 251:2010), Yeast and Mould (SLS 516 part 2:1991) were done for samples. For market survey data were collected using the method of filling questionnaire to each person using sixty sample sizes.

The sensory data were analyzed using Minitab 15 software using, Freidman test, one way analysis of variance (ANOVA) and one way analysis of variance (ANOVA)-Unstacked, followed by Turkey's test for mean comparison for chemical analysis results. The criterion for statistical significance was $p<0.05$. Results were expressed as mean \pm SD (standard deviation). The questionnaire data were analyzed by using MS Excel 2010 and the correlation was taken by Chi-square analysis in Minitab 15 software.

\section{Results and Discussion}

Number of preferences recorded for sample A (10\% kohila flour added sample) and B (15\% kohila powder added sample), demonstrated that Sample A is the best one (Table 2). Second sensory evaluation was carried out to investigate the acceptability of each attributes in biscuit samples. The organoleptic properties such as color, taste, smell, crispiness and overall texture were examined. There was a significant difference in each attributes between four samples $(p<0.05)$ and the sample A scored higher for each attribute than other samples. Figure 1 showed, addition of sucralose positively influenced for some sensory characteristics as taste, color, smell but less score than sample A. All attributes of four biscuit samples were scored high. Among the tested sensory characteristics of sample A crispiness had the lowest score.

General comments by the panelists regarding sensory attributes were also evaluated. The most common criticisms were related after taste of sample B. Complaints regarding after taste were not recorded for the other three samples. Therefore, high percentage of Kohila flour may be responsible for after taste of the biscuit in sample B. Although Sample A contained sugar than sucralose added sample D, it was able to maintain higher consumer acceptability than sample D in the present study, possibly due to the artificial flavor in Sample D. The artificial taste derived from sucralose added sample might be due to the addition 


\begin{tabular}{|l|c|c|c|c|}
\hline Ingredients (g/100g flour) & C & A & B & D \\
\hline Kohila powder & 0 & 500 & 750 & 500 \\
\hline Wheat flour & 2940 & 2440 & 2190 & 3012 \\
\hline Palm oil & 800 & 800 & 800 & 900 \\
\hline Sugar & 800 & 800 & 800 & 0 \\
\hline Whey powder & 23.5 & 23.5 & 23.5 & 27.5 \\
\hline Salt & 8 & 8 & 8 & 9 \\
\hline Lecithin & 40 & 40 & 40 & 55 \\
\hline Sodium bicarbonate & 6 & 6 & 6 & 8 \\
\hline Ammonium bicarbonate & 15 & 15 & 15 & 19 \\
\hline Vanila flavor & 1.4 & 1.4 & 1.4 & 1.9 \\
\hline Sucralose & 0 & 0 & 0 & 1.0 \\
\hline Water & 500 & 500 & 500 & 600 \\
\hline
\end{tabular}

C: control (without Kohila flour); A: 10\% added Kohila flour; B: 15\% added Kohilaflour;D: $10 \%$ added kohila flour and suralose.

Table 1: Biscuit Formulations.

\begin{tabular}{|c|c|}
\hline Treatment & Preference $\%$ \\
\hline Biscuits containing $10 \% \mathrm{KF}$ & $77 \%$ \\
\hline Biscuits containing15\% KF & $23 \%$ \\
\hline \multicolumn{2}{|c|}{ KF: Kohila Flour } \\
\hline
\end{tabular}

Table 2: Preference for Two Samples.

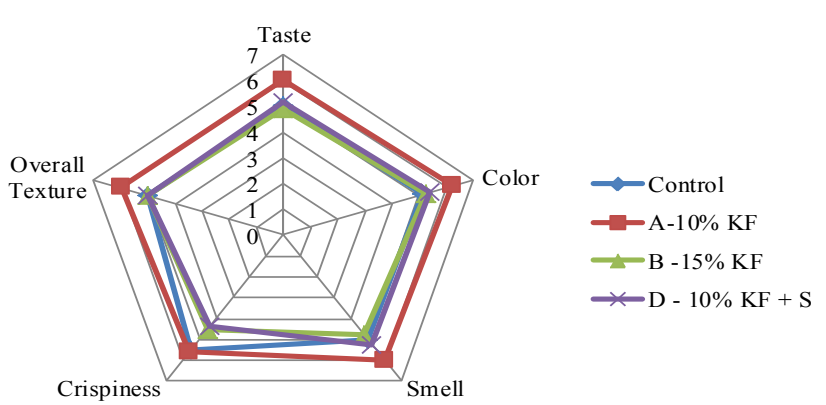

Figure 1: Mean Variation for Each Attributes in Four Treatments

A 1-7 point hedonic scale $1=$ extremely dislike, $2=$ moderately dislike, $3=$ slightly dislike,4=neither like nor dislike, $5=$ slightly like, $6=$ modrrately like, $7=$ =xtremely like. KP: Kohila Powder, S: Sucralose.

of sucralose. That can be reduced by adding natural sweetener as stevia, which is 100-150 times sweetened than sucrose. But cost will become high, when use stevia for sugar substitution [18].

However, these findings suggested that $10 \%$ Kohila flour added sample was the best one and through the improvement of each attributes of sucralose added sample could be able to become more acceptable and appealing sample.

Sucrose is the main sugar used in short dough biscuit formula, and it plays an important role in the biscuit manufacturing [19]. But substitution of sugar with nonnutritive sweeteners is used for food production in worldwide to reduce the calorie amount [20]. Sucralose is an artificial nonnutritive sweetener which is 600 times sweeten than sucrose and is stable at high temperature, use for production of food for the people with NCDs.

Energy value for $15 \%$ Kohila flour added sample(B) and biscuit containing sucralose (D) were significantly similar $(p>0.05)$ and lower than $10 \%$ Kohila flour(A) incorporated sample $(p<0.05)$, may be due to the reduction of wheat flour content and sugar content respectively. But with sugar substitution energy reduction was not in large value compare with sample A, may be due to the increment of fat content with reduction of sugar content. However for production of Kohila

flour added biscuit for NCDs having people as diabetics' patients the fat replacement should be used as fat mimetics. Fat mimetics are substances that imitate organoleptic or physical properties of triglycerides but which cannot replace fat on a one-to-one, gramfor-gram basis. Fat mimetics, often called protein (whey protein concentrate) or carbohydrate based fat replacers (modified starches and dextrins, nondigestible complex carbohydrates as cellulose) and have low caloric value ranges from $0-4 \mathrm{kcal} / \mathrm{g}$. Many fat mimetics are suitable for baking [21]. Therefore, further studies are needed to replace fat and further reduce the calorie content in those samples.

The protein content of sample A and B were significantly lower than the control $(p<0.05)$ while the protein content of sample D had the highest value. Protein contribution to the followed recipe mainly done by wheat flour which was contained $8-9 \%$ of gluten in dry basis as major protein. Highest protein content in the sample $\mathrm{D}$ may be due to the high amount of wheat flour than other samples, while sample D had the lowest protein content, may be due to the lowest wheat flour content than other samples. However, biscuits containing Kohila powder had high protein content than fiber rich digestive biscuit available in the market (Table 3).

Major fat source in the samples was palm oil which contained saturated fat than unsaturated fat as monounsaturated and polyunsaturated fat. Monounsaturated fat content is high in palm oil than polyunsaturated fat and this is positively affected for the health $[22,23]$. Fat content in soft dough biscuit is normally higher than hard dough biscuits to get the characteristic texture [24]. Sample A contained low amount of fat than other samples and became healthier one. The sucralose added sample contained the highest amount of fat due to increasing the oil percentage used and it was significantly different from other samples $(p<0.05)$. Even though sugar was substituted with sucralose, due to the increase of the saturated fat content, could be negatively affected for the health. But the fat content in Sample A was lower than the normal soft dough biscuit. Therefore, health wise it is better than other types of soft dough biscuits.

The sugar content of sample A was higher than other samples and by substituting sugar with sucralose could be able to reduce the total sugar content. Carbohydrate contribution for biscuit samples was normally done by sugar and wheat flour. Carbohydrate content was lower in sample with sucralose, may be due to the reduction of sugar. Therefore, in order to carbohydrate and sugar content, sucralose added sample was better than Sample A.

Total ash content (mineral matter) was significantly high in Kohila flour added biscuits than control $(p<0.05)$, except sample D. Sample B had significantly higher amount of ash $(p<0.05)$ than the sample A. This may be due to the $5 \%$ excess addition of Kohila powder. The reason for lowest total ash content in D may be due to reduction of the sugar content.

Even though there was a significant difference between moisture contents of samples $(p<0.05)$, the initial moisture contents in all four sample were within the acceptable level (moisture content lower than 3.00). Sugar draws moisture from the atmosphere, then the moisture content of sucralose added sample should be lower than others. The reason for the increment of moisture content in sample D from sample A may be incorporation of higher water content or the higher atmospheric humidity condition during packaging. The term water activity $\left(\mathrm{a}_{\mathrm{w}}\right)$ refers to the unbound water and water activity of normal soft dough biscuit is 3.00 . The water activity of a food was not the same as its moisture content. Although moist foods are likely to have greater 
Citation: Pupulawaththa AW, Perera ODAN, Ranwala A (2014) Development of Fiber Rich Soft Dough Biscuits Fortified with Kohila (Lasia spinosa) Flour. J Food Process Technol 5: 395. doi:10.4172/2157-7110.1000395

Page 4 of 8

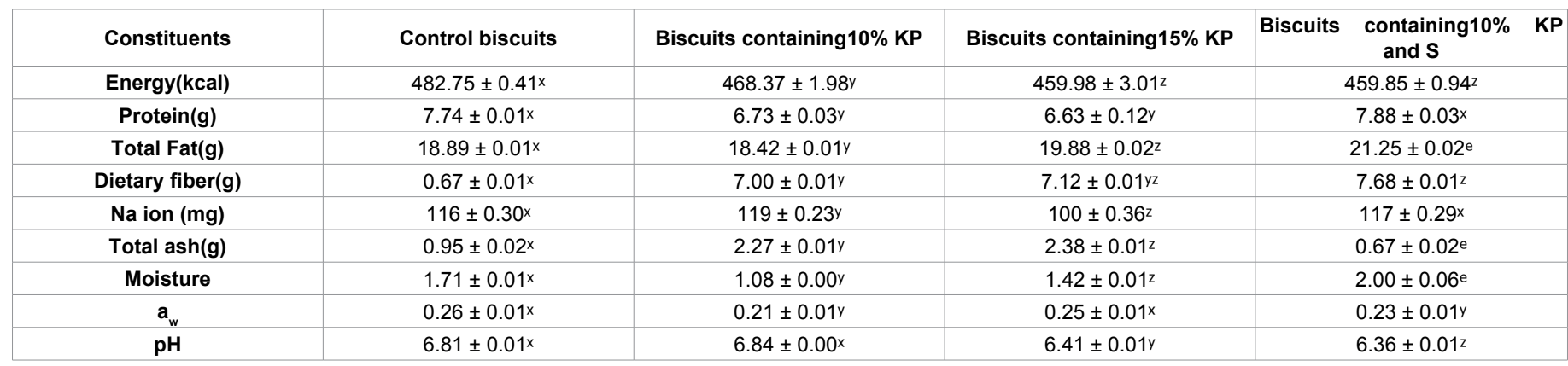

Means \pm standard deviation in each raw with the different lowercase superscript letters are significantly different $(p<0.05)$.

KP:Kohila Powder, S: Sucralose. Determination was done in triplicate.

Table 3: Nutrtional Characteristics of Kohila Powder Added Biscuits and Control for $100 \mathrm{~g}$ of Sample

water activity than are dry foods, this is not always so; in fact a variety of foods may have exactly the same moisture content and yet have quite different water activities. Therefore, if the sample $\mathrm{D}$ had the highest moisture content, it was not had the highest water activity value. The reason may be high bound water presented in the sucralose added sample than control and sample B. All three samples had lower water activity when compared with control and all were in the acceptable level.

The $\mathrm{pH}$ of control and sample A powder added samples were within the standard $\mathrm{pH}$ range of soft dough biscuits $(\mathrm{pH}$ 6.8-7.2: SLS 251:2010). Other two samples had significantly lower pH when compared with the control $(p<0.05)$.

Women need $25 \mathrm{~g}$ of dietary fiber per day and men should get $38 \mathrm{~g}$ per day. Fiber rich biscuits are not only good for people suffering from NCDs, but also good for people who are suffering from constipation, and intestinal diseases. Dietary fiber was mainly incorporated by wheat flour and Kohila flour. Kohila flour added samples had significantly higher $(p<0.05)$ amount of dietary fiber than control. Therefore, Kohila flour addition was highly associated with the dietary fiber. Sample $B$ had lower increment of dietary fiber than sample A. Therefore, by increasing the added Kohila powder content in less percentage may not increase the dietary fiber to a considerable amount. Sample D contained the highest amount of dietary fiber may be due to the increasing the amount of wheat flour percentage other than Kohila flour in the sample. Therefore, Kohila flour addition was helped to develop more nutritious biscuit than normal soft dough biscuit as control. Further developing Kohila flour added biscuits by reducing saturated fat content, will be contributed to the healthy food to prevent from non-communicable diseases (NCDs).

Sodium ion content in control and sample D were not significantly different $(p>0.05)$. But compared to control, sample A contained significantly $(p<0.05)$ high amount of sodium. Normal soft dough biscuit, available in the market contains higher sodium content than those samples (Health Canada, 2008). Therefore, Kohila powder added biscuit may be good for heart patients by considering low sodium content than other soft dough biscuits.

A heavy metal is a member of a loosely defined subset of elements that exhibit metallic properties. Living organisms require varying amounts of "heavy metals". Iron ( $\mathrm{Fe})$, Copper $(\mathrm{Cu})$, Molybdenum (Mo), and Zinc ( $\mathrm{Zn})$ are required by humans. Excessive levels can be damaging to the organism. Other heavy metals such as Mercury $(\mathrm{Hg})$, Arsenic(As), Cadmium $(\mathrm{Cd})$ and Lead $(\mathrm{Pb})$ are toxic metals and their bioaccumulation over time in the bodies of animals can cause serious illnesses.
Heavy metals can enter a water supply by industrial and consumer waste, or even from acidic rain breaking down soils and releasing heavy metals into streams, lakes, rivers, and groundwater. These heavy metals can be absorbed by the crops which are grown in water accumulated areas. In the, four biscuits samples $\mathrm{Cd}, \mathrm{Cr}, \mathrm{Mo}, \mathrm{Pb}, \mathrm{Sb}, \mathrm{As}$ and $\mathrm{Se}$ were not presented (Table 4). Even though Kohila cultivated mainly in swamps, riverbanks and other rain water accumulated places, the content of those metals in biscuit samples were zero. The recommended maximum level in biscuits for $\mathrm{As}$ and $\mathrm{Pb}$ are $1 \mathrm{mg} / \mathrm{kg}$ and $2 \mathrm{mg} / \mathrm{kg}$ respectively (SLS 251:2010, 6.4).The reason for the absence of above heavy metals in biscuits with Kohila flour may be the soil in the Kohila which was taken for the production of biscuits, cultivated area was not rich with those metals.

Aluminium (Al), Copper $(\mathrm{Cu})$, Iron (Fe), Nickel $(\mathrm{Ni})$ and Zinc $(\mathrm{Zn})$ were presented in four biscuit samples while Beryllium (Be) were presented only in biscuit containing Kohila powder. Beryllium may be contributed by Kohila powder. Some of these elements are actually necessary for humans in minute amounts $(\mathrm{Co}, \mathrm{Cu}, \mathrm{Cr}, \mathrm{Mn}, \mathrm{Ni})$ and for those essential metals there is a range of intake over which their supply is adequate to the body (Fe $8-18 \mathrm{mg} /$ day, $\mathrm{Mn} 1.8-2.3 \mathrm{mg} /$ day, $\mathrm{Cu} 0.9 \mathrm{mg} /$ day, $\mathrm{Zn} 8-11 \mathrm{mg} /$ day, Ni $0.5 \mathrm{mg} /$ day). However, beyond this ranges, deficiency and toxic effects are observed [25].

The Zn content was significantly high $(p<0.05)$ in biscuit with Kohila flour than control and it may be happened with addition of Kohila powder. $\mathrm{Zn}$ reduces immune function and the levels of high density lipoproteins. But that Zinc may not be presented in the form which can be absorbed to the body. However Zinc deficiency in children causes growth retardation, delayed sexual maturation, infection susceptibility, and diarrhea.

The $\mathrm{Cu}$ content was significantly similar in control and biscuits with Kohila flour ( $p>0.05)$. Addition of Kohila flour does not incorporate copper. Copper is essential to all living organisms as a trace dietary

\begin{tabular}{|c|c|c|c|}
\hline Heavy metal(ppm) & Control biscuits & Biscuits -10\% KF & Biscuits -15\% KF \\
\hline $\mathbf{A l}$ & $10.05 \pm 2.05$ & $31.90 \pm 7.92$ & $31.90 \pm 7.92$ \\
\hline $\mathbf{B e}$ & $0.00 \pm 0.00$ & $9.05 \pm 0.78$ & $9.25 \pm 0.78$ \\
\hline $\mathbf{C u}$ & $6.25 \pm 0.50$ & $5.30 \pm 0.00$ & $6.55 \pm 0.21$ \\
\hline $\mathbf{F e}$ & $26.45 \pm 2.76$ & $47.95 \pm 1.91$ & $231.65 \pm 17.04$ \\
\hline $\mathbf{N i}$ & $0.90 \pm 0.57$ & $0.85 \pm 0.21$ & $0.95 \pm 0.21$ \\
\hline $\mathbf{Z n}$ & $10.95 \pm 3.46$ & $231.65 \pm 17.04$ & $229.70 \pm 1.13$ \\
\hline
\end{tabular}

Means \pm standard deviation in each raw with the different lowercase superscript letters are significantly different $(p<0.05)$. KF:Kohila Flour. Determination was done in duplicate.

Table 4: The Heavy Metal Content in Biscuit Samples. 
mineral because it is a key constituent of the respiratory enzyme complex cytochrome c oxidase [26].

Significantly high amount of iron content was contained in sample B compare to the control $(p<0.05)$. Iron content increment may be occurred with the addition of Kohila flour. A high supplementation of Fe causes pathological events such as the iron oxides deposition in Parkinson's disease. The Dietary Reference Intake (DRI) lists the Tolerable Upper Intake Level (UL) for adults as $45 \mathrm{mg}$ /day. For children under fourteen years old the UL is $40 \mathrm{mg} /$ day. If the iron content was high it may be not presented in the form of $\mathrm{Fe}^{2+}$ form (only $\mathrm{Fe}^{2+}$ is absorbed by the human body). Generally plant contains iron which has very low bioavailability ( $\mathrm{Fe}^{3+}$ form). However, most preferred biscuit from sensory, with $10 \%$ Kohila flour added sample, contained significantly $(p<0.05)$ low amount of iron than other rejected sample B.

Ni content was not significantly different $(p>0.05)$ among the three samples, therefore by Kohila powder addition nickel contribution was less. Aluminium was significantly high in Kohila powder added biscuits $(\mathrm{p}<0.05)$ than control. Aluminium has no known biological role and its classification into toxic metals is controversial. Individuals with healthy kidneys can be exposed to large amounts of aluminium with no ill effects. Therefore this aluminium content may not negatively affect the human body.

However without rejecting the biscuits added kohila flour, further experiments are needed to carry out to check the bioavailability of ions which are presented in kohila flour added biscuits.

Antioxidant capacity (Radical DPHH scavenging capacity) of Kohila flour added biscuits were significantly higher $(p<0.05)$ than control (Table 5). This is given an additional benefit to the consumers to prevent from diseases as cancers [27]. Highest value was determined from sample B might be due to the addition of excess 5\% Kohila flour than sample A. Some heat sensitive antioxidants may be destroyed by baking. Therefore, raw kohila flour may be contained higher antioxidant capacity. Some antioxidant compounds are destroyed when baking [28]. But phenolic acids retain their antioxidant activity after the baking process [29]. However further research may be needed to evaluate the

Total plate count and coliform count were high in Kohila flour while mould and yeast counts were zero, may be due to the low moisture content. Microorganisms could be introduced to the Kohila powder after production as during handling. Although the $\mathrm{pH}$ of the Kohila flour was favorable for the growth of yeast and mould $(\mathrm{pH} \mathrm{5-6)} \mathrm{the}$ count were zero may be due to the low water activity. Escherichia coli present at water activity above 0.95 and was not present in Kohila flour indicating no fecal contamination. Oven temperature was maintained at about $60^{\circ} \mathrm{C}$ during drying which was the danger zone of the bacterial growth $\left(4^{\circ} \mathrm{C}-60^{\circ} \mathrm{C}\right)$. But microbes need at least over 0.6 water activity level to be present in a food material. Therefore, Kohila flour may not be contained microbes other than introduction during handling. Good handling practices as using hot water to clean the cutting boards, knives, hands, and Kohila pieces may also be helped for the absence of Escherichia coli.

Almost all microorganisms were destroyed during baking due to high temperature. But during packaging cross contamination could be occurred due to handling of biscuits. Other than that water in food which is not bound to food molecules can support the growth of bacteria, yeasts and molds. There was no any support to the microbial growth at this water activity range of those samples. Bacteria usually require at least 0.91 water activity, and fungi require at least 0.7 water activity, and microorganisms can't be able to survive at below 0.6 water activity. The risk of food poisoning must be considered in low acid foods $(\mathrm{pH}>4.5)$ with a water activity greater than 0.86 [30]. But due to lower water activity (related to free water) range of those biscuit samples were not having the risk of growing microorganisms related to food poisoning [31-42].

Initial total plate count and coliform counts in biscuits were may be due to the cross contamination. Yeast and mould counts were zero for all four samples due to the low moisture content of samples. Escherichia coli was absent in all samples, indicating that there was no any fecal contamination. Total plate count of control, sample A, and sample B were not significantly difference $(p>0.05)$, while total plate count of sample D was significantly $(p<0.05)$ different from others. sample A had significantly $(p<0.05)$ different coliform count compare to others (Table 6) [43]. Reasons for these differences may be the poor handling practices. However, microbial contents of all biscuit samples were below maximum standard levels. Maximum aerobic plate count of biscuit is $5 \times 10^{4} \mathrm{cfu} / \mathrm{g}$, maximum yeast and mould count is $5 \times 10^{3}$, and coliform (MPN) is $5 \times 10^{2} \mathrm{cfu} / \mathrm{g}$ (SLS 251:2010,6.3.1) [44-57].

Shelf life determination was done, using sample A which was the most preferred sample according to the sensory evaluation. The peroxide value is a measure of the peroxides contained in the sample. Lipid oxidation leads to deterioration of oils which form off-flavors and off-odors. Peroxides are intermediates in the lipid oxidation and used as an index of lipid oxidation (rancidity). Determination of peroxide value of biscuits samples were done initially and following two weeks of aging. A sample is said to be rancid when peroxide value reaches above $10 \mathrm{mEq} / \mathrm{kg}$. Although the peroxide value content in the sample was high in second week compare to initial value, the weekly increment of peroxide value was low. For the biscuit preparation palm oil was used as the oil source. The unsaturation is lower than saturation in palm oil. Furthermore, it contain low amount of polyunsaturated fat content [58]. Basically oils with a high degree of unsaturation are most susceptible to oxidative rancidity. $\mathrm{Fe}, \mathrm{Cu}, \mathrm{Ni}$ can be act as catalysts in lipid oxidation. Iron act as a catalyst in peroxide formation by converting $\mathrm{Fe}^{2+}$ complex to $\mathrm{Fe}^{3+}$ complex. Although the iron content was high in kohila biscuit than control the peroxide formation may be controlled due to the high antioxidant activity of the biscuit $[59,60]$. Furthermore, the exposure of lipids to reactive oxygen species and

\begin{tabular}{|c|c|}
\hline Treatment & \%DPPH Scavenging Activity \\
\hline Control biscuits & $3.20 \pm 0.30$ \\
\hline Biscuits $-10 \%$ KF & $45.05 \pm 0.23$ \\
\hline Biscuits -15\% KF & $47.83 \pm 0.76$ \\
\hline Biscuits -10\% KF \& S & $45.10 \pm 0.12$ \\
\hline
\end{tabular}

Means \pm standard deviations in each column with the different lowercase superscript letters are significantly different $(p<0.05)$.KP: Kohila Flour, $S$ : Sucralose. Determination was done in triplicate.

Table 5: The Dpph( 2,2-Diphenyl-1picrylhydrazyl Radical) Scavenging Activity (\%) of Biscuit Samples

\begin{tabular}{|l|l|l|c|c|c|}
\hline Treatment & $\begin{array}{l}\text { TPC } \\
\text { (cfu/g) }\end{array}$ & $\begin{array}{l}\text { Coliform } \\
\text { (cfu/g) }\end{array}$ & $\begin{array}{l}\text { Mould } \\
\text { (cfu/g) }\end{array}$ & $\begin{array}{l}\text { Yeast } \\
\text { (cfu/g) }\end{array}$ & E.coli \\
\hline Control biscuits & $29.67 \pm 0.58$ & $2.00 \pm 1.00$ & 0 & 0 & (-)ve \\
\hline Biscuits -10\% KF(A) & $27.33 \pm 4.04$ & $3.67 \pm 0.58$ & 0 & 0 & (-)ve \\
\hline Biscuits -15\% KF(B) & $30.00 \pm 1.00$ & $1.67 \pm 0.58$ & 0 & 0 & (-)ve \\
\hline Biscuits -10\% KF and S(D) & $49.67 \pm 0.58$ & $2.00 \pm 1.00$ & 0 & 0 & (-)ve \\
\hline
\end{tabular}

Means \pm standard deviation in each column with the different lowercase superscript letters are significantly different $(p<0.05)$. KF:Kohila Flour, S: Sucralose.

Table 6: Initial Microbial Level in Biscuit Samples 
UV-radiation were reduced by packing the products in metalized polypropylene materials with lower UV and oxygen transmission rate. This may also be terminated the initiation process of lipid oxidation. During production, high temperature range $\left(250-300^{\circ} \mathrm{F}\right)$ was used, this may helped to reduce the lipid oxidation by enzyme inactivation [6168].

Moisture and water activity were increased with time, but had very little. The moisture contents were significantly same in first four weeks $(p>0.05)$ and significant $(p<0.05)$ increment was occurred after $4^{\text {th }}$ week and after $9^{\text {th }}$ week. The change in moisture content between initial value from final value was 0.07 . The rejection moisture level in biscuit is 3 [69]. The water activity of biscuit samples were below normal level $\left(a_{w} 3\right)$, means the unbound water content was low in the biscuit sample. Water activities of biscuits were same in $2^{\text {nd }}, 3^{\text {rd }}$ weeks, in $5^{\text {th }}, 6^{\text {th }}, 7^{\text {th }}$, $8^{\text {th }}$ weeks and again same in last $9^{\text {th }}, 10^{\text {th }}$ weeks (Figure 2). Significant $(p<0.05)$ increment of water activity was observed after $2^{\text {nd }}, 3^{\text {rd }}, 4^{\text {th }}$, and $9^{\text {th }}$ weeks. Water activity different from initial value and final value was 0.03 . The reason of this little increment in moisture and water activity may be the suitable properties of packaging material as low moisture transition rate and low relative humidity inside the packaging material. If those biscuit was exposed to humid air ( $a_{w}$ was higher than biscuits), the biscuit would absorb the water from air, and therefore packaging with lower water transition rate was required to maintain condition of the biscuit in acceptable level [70-72]

Even though monthly total plate count was significantly different $(p<0.05)$, it had very little increase with time. Yeast and mould counts were zero with time may be due to low water activity of biscuits. Reasons for total plate counts at low water activity may be incorporation of microorganisms during handling of biscuits [73].

Therefore by considering the shelf life determination results, the biscuits were within shelf life level and analysis should be further carried out to determine the exact shelf life of the biscuits.

There was a correlation between gender and preference to sugar added biscuits and non sugar added biscuits $(p<0.05) .77 \%$ of males were preferred non sugar added biscuits while $47 \%$ females were preferred non sugar added biscuits. The results showed that there was a correlation between age group and preference to the sugar addition $(p<0.05) .71 \%$ of adults were preferred sucralose added biscuits and $55 \%$ elders were preferred sugar added biscuits. The $64 \%$ of adolescents were preferred sugar added biscuits. The reasons for those may be adolescents normally didn't consider their health and preferred tasty foods. Adults faced to lot of non-communicable diseases (NCDs) as diabetics and considered about the health states than adolescents. Elders again preferred sweet foods may be due to lack of perception of taste [74].

There was a correlation between health condition and preference to sugar addition $(p<0.05)$. People who had NCDs diseases as diabetics should be preferred sucralose added biscuits, but according to this survey results, diseases having people preferred sugar added biscuits (67\%). Most people who didn't have diseases preferred sucralose added biscuits $(67 \%)$. The people who didn't have diseases may be tried to prevent from any NCDs occurrence by refusing the sugar added foods. However further surveys were needed to clarify this clearly. Other than preference for sucralose addition people without any NCDs preferred to eat fiber fortified biscuits $(60 \%)$ and disease having people most preferred to eat non fiber fortified biscuits. However statistically there was no any relationship between health condition and preference of fiber fortified biscuits.
There was a correlation between educational level and preference to the sugar addition to the biscuits $(p<0.05)$. Graduates or highly educated people preferred to eat nonsugar added biscuits $(81 \%)$. The reason may be understand the benefits of accepting healthy foods when increasing the educated condition. But people having only G.C.E O/L and $\mathrm{A} / \mathrm{L}$ most preferred to eat sugar added biscuits. The reason may be carelessness about the health condition.

There was no correlation between education level and preference for fiber fortified biscuits ( $p>0.05)$. But $55 \%$ highly educated people preferred fiber fortified biscuit, and $75 \%$ of people having G.C.E. A/L also preferred fiber fortified biscuits. $62 \%$ of people only having G.C.E. $\mathrm{O} / \mathrm{L}$ highly preferred non fiber fortified biscuits. However further surveys are needed to clarify these things accurately.

$52 \%$ of people preferred to pay Rs. $40.00-49.00$ for an $80 \mathrm{~g}$ of fiber added packet of biscuit and preferred to buy it from retail shops, may be due to easiness to buy at any area $[75,76]$.

When purchasing a packet of biscuit people mostly considered

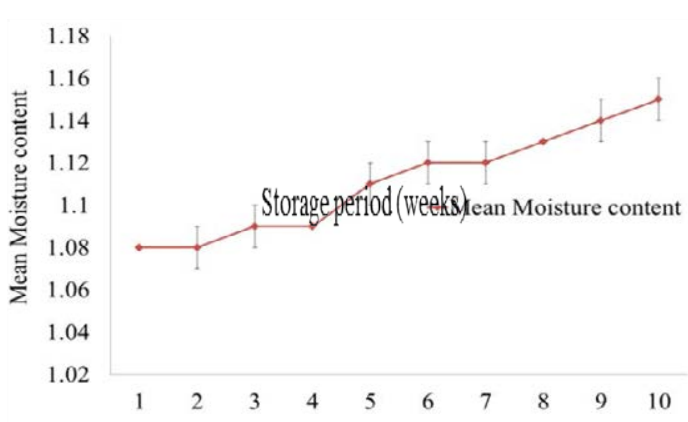

(a)

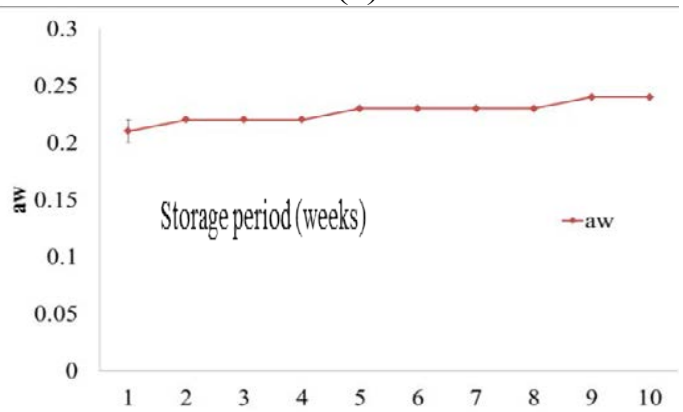

(b)

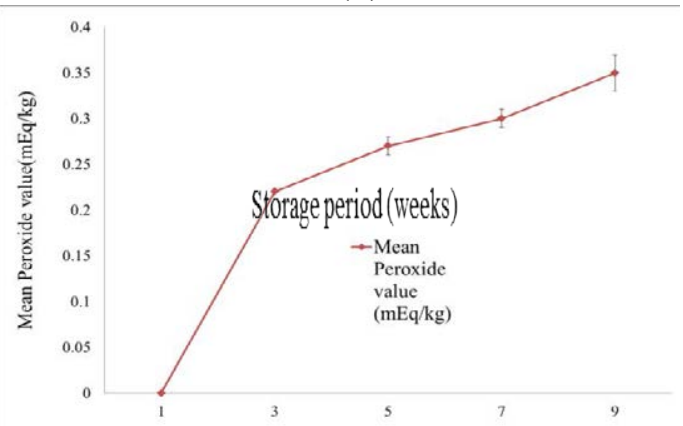

(c)

Figure 2: Changes In (A) Moisture Content, Water Activity $\left(A_{w}\right)(B)$ And Peroxide Value (C) With Time, In Biscuit Added $10 \%$ Kohila Flour. The error bars are indicated standard deviation $(n=3, p<0.05)$. 
Citation: Pupulawaththa AW, Perera ODAN, Ranwala A (2014) Development of Fiber Rich Soft Dough Biscuits Fortified with Kohila (Lasia spinosa) Flour. J Food Process Technol 5: 395. doi:10.4172/2157-7110.1000395

Page 7 of 8

about the sensory qualities as taste and color of the biscuit inside, then price, brand name of manufacture, reliability, appearance and attractiveness, nutritional composition, convenience of purchasing, guarantee of safety and hygiene, packaging, ability to be kept for a long time, having little /no added preservatives, and adequate information given on label were considered.

\section{Conclusions}

The sample which was fortified with $10 \%$ Kohila flour was the most consumer preferred sample that contained a significant amount (7 $\mathrm{g} / 100 \mathrm{~g}$, on dry basis) of dietary fiber $(\mathrm{p}<0.05)$. Addition of sucralose ensured a highly nutritious low energy product. Further replacing palm oil with protein based and carbohydrate fat replacers may help further reduction of energy and saturated fat content. The iron content was high and toxic heavy metals were absent in fortified biscuits. The heavy metal content may vary with place where the Kohila was purchased and the iron may be not in bioavailable form. Further studies should be done to confirm these observations. Market survey showed that there was a correlation between preference for fiber fortified biscuits and educational level $(\mathrm{p}<0.05)$. However sample size of this survey was sixty and, is insufficient to obtain an accurate result. Therefore, further market surveys are needed to draw accurate conclusions.

\section{References}

1. Chopra M (2002) Globalization Diets and Non communicable diseases. World Health Organization.

2. Pekka P, Pirjo P, Ulla U (2002) Influencing public nutrition for non-communicable disease prevention: from community intervention to national programme-experiences from Finland. Public Health Nutr 5: 245-251.

3. Eastwood M (1999) Principles of Human Nutrtion (2ndedn) United Kingdom: Anespen.

4. Marika $L$ (2006) Added $\beta$-glucan as a source of fibre for consumers. Journal of Human Nutrtion and Dietetics 17: 231-239.

5. Robert JS (2008) Dietary Determinants of Obesity. The Concise Oxford Dictionary.

6. Mervat E (2011) Evaluation of physico-chemical properties of toast breads fortified with pumpkin (Cucurbitamoschata) flour. In the 6th Arab and 3rd International Annual Scientific Conference. Egypt.

7. Bhawna C, Gurmukh S, Kumbhar BK (2013) Development of Low-Fat Soft Dough Biscuits Using Carbohydrate-Based Fat Replacers. International Journal of Food Science.

8. Wijewardene K, Mohideen MR, Mendis S, Fernando DS, Kulathilaka T, et al (2005) Prevalence of hypertension, diabetes and obesity: baseline findings of a population based survey in four provinces in Sri Lanka. Ceylon Med J 50 : $62-70$

9. Marles RJ, Farnsworth NR (1995) Antidiabetic plants and their active constituents. Phytomedicine 2: 137-189.

10. Pankaj S, Dibakar CD (2013) Mineral content of some wild green leafy vegetables of North-East India. Journal of Chemical and Pharmaceutical Research 5: 117-121.

11. Shefana AG, Ekanayake S (2009)Some nutritional aspects of Lasiaspinosa (kohila). Vidyodaya Journal of Sicence14: 59-64.

12. Priyadarshani AMB, Jansz ER (2006) The effect of maturity on carotenoids of Lasiaspinosa stem and the effect of cooking on in-vitro bioaccessebility of carotinoids.Journal of National Science foundation Sri Lanka 34: 131-136.

13. Goshwami D, Mostafizur R, Abdul M, Saiful I, Mukhtar A (2012) Antioxidant Property, Cytotoxicity and Antimicrobial Activity of Lasiaspinosa Leaves. Nepa Journal of Science and Technology 13: 215-218.

14. Durajan G, Mostafizur R, Abdul M, Saiful I (2012) Antioxidant Property, Cytotoxicity and Antimicrobial Activity of Lasiaspinosa Leaves. Nepal Journal of Science and Technology 13: 215-218.

15. Ibrahim M NM,Ravindranath S, Balasubramaniam S (1988) Journal of Food
Science1: 17-80

16. Jian L (2009) Total Anthocyanin Content in Blue Corn Cookies as affected by Ingredients and oven types. Journal of Food Science 3: 17-80.

17. Daina K, Ilga G, Marina R, Maija K (2012) Production of Biscuits with Higher Nutritional Value. Journal of Proceeding of the Latvian academy of sciences 66: $113-116$

18. Christophe G, Judith WR, Samuel SG, Lyn MS, Rachel KJ, et al. (2012) Nonnutritive Sweeteners: Current Use and Health Perspectives: A Scientific Statement from the American Heart Association and the American Diabetes Association. Journal of the American Heart Association 126: 509-519.

19. Laura L, Katleen JRV, Albert J, Teresa S (2012) Understanding the effect of sugar and sugar replacement in short dough biscuits. Journal of Food and Bioprocess Technology 34: 192-248.

20. Racjeanne G, Spidel M, Kristy L, Catherine J (2004) Canadian Diabetes Association National Nutrition Committee Technical Review: Non-nutritive Intense Sweeteners in Diabetes Management. Canadian Journal of Diabetes 28: 385-399.

21. Zoulia E, Oreopoulou V, Kounalaki E (2002) Effect of fat and sugar replacement on cookie properties. Journal of the Science of Food and Agriculture 82: 16371644.

22. Health Canada (2013) E.coli.

23. Health Canada (2008) Nutrient Value of Some Common Foods

24. Laura L, Ana S, Teresa S, Susana MF (2011) Performance of a resistant starch rich ingredient in the baking and eating quality of short-dough biscuits. Journal of Food Science and Technology 44: 737-746.

25. Ahmed KS, Mohomad AR (2005) Heavy metals (Cd, Pb) and trace elements $(\mathrm{Cu}, \mathrm{Zn})$ contents in some foodstuffs from the Egyptian market. Journal of Agriculture Science 17: 34-42.

26. Jorherm L, Sundstroem B (1993) Levels of lead, cadmium, zinc, copper, nickel, chromium, manganese and cobalt in foods on the Swedish market, 1983-1990. Journal of Food Composition and Analysis 6: 223-241.

27. Park SH, Lim HS, Hwang SY (2012) Evaluation of antioxidant, rheological, physical and sensorial properties of wheat flour dough and cake containing turmeric powder. Food Sci Technol Int 18: 435-443.

28. Ei-Sayed M, Abdel-A, Robalski I (2008) Bioactive Compounds and thei Antioxidant Capacity in Selected Primitive and Modern Wheat Species. The open Agriculture Journal 2:7-14

29. Han HM, Koh BK (2011) Antioxidant activity of hard wheat flour, dough and bread prepared using various processes with the addition of different phenolic acids. J Sci Food Agric 91: 604-608.

30. Nagi HPS, Kaur J, Dar BN, Sharma S (2012) Effect of Storage Period and Packaging on the Shelf Life of Cereal Bran Incorporated Biscuits. American Journal of Food Technology 7: 301-310.

31. Eun-Hye L, Hye JY, Ha MS, Dong HB (2010) Development of Banana Pee Jelly and Its Antioxidant and Textural Properties. Journal of Food Science \& Biotechnology 19: 449-455.

32. Yadav AK, Temjenmongla (2012) Efficacy of Lasiaspinosa leaf extract in treating mice infected with Trichinellaspiralis. Parasitol Res 110: 493-498.

33. Popkin BM (2006) Global nutrition dynamics: the world is shifting rapidly toward a diet linked with noncommunicable diseases. Am J ClinNutr 84: 289-298.

34. Bawalan DD (2000) The Economics of Production,Utilization and Marketing of Coconut Flour from Coconut Milk Residue. Center for Occupational Research and Development 16: 1-13.

35. Iwegbue MAC (2012) Metal Contents in Some Brands of Biscuits Consumed in Southern Nigeria. American Journal of Food Technology 7: 160-167.

36. Durajan G, Mostafizur R, Abdul M, Saiful I (2012) Antinociceptive activity of leaves of Lasiaspinosa. Archives Journal of Applied Science 4: 2431-2434.

37. Eissa A, Hussein AS, Mostafa BE (2007) Rheological properties and quality evaluation of egyptian balady bread and biscuit supplemented with flours of ungerminated and germinated legume seeds or mushroom. Polish Journal of Food and Nutrition Sciences 57: 487-496.

38. Fife BND (2000) The winder of coconut oil. Journal of Health Miracle of Coconut Oil. p . 33-53. 
Citation: Pupulawaththa AW, Perera ODAN, Ranwala A (2014) Development of Fiber Rich Soft Dough Biscuits Fortified with Kohila (Lasia spinosa) Flour. J Food Process Technol 5: 395. doi:10.4172/2157-7110.1000395

39. Firdusi SN, Neog N, Barooah MS (2012) Phytochemical Analysis of Lasiaspinosa and Alpinianigra, Potential Medicinal Plants of Assam. International Journal of Phytomedicines and Related Industries 4: 170-173.

40. Fukuda Y, Nakata S (1999) Effects of roasting temperature in sliced almonds \& sesame seeds on the antioxidant activities. Journal of the Japanese society for food science \& Technology 46: 786-791

41. Gates FK, Speirs C, Tucker G (2012) Healthy Food Manufacturing: Process Challenges \&Solutions for Salt Reduction, Fat Reduction, and Fiber Enhancement Strategies for developing healthier bakery products. In AACC International annual meeting. United Kingdom.

42. Gayathri P, Sewandi S, Jansz ER (2007) Variation of dietary fibre content and gel-chromatography profile of the fruit pulp of four morphologically different fruit types of palmyrah. Journal of National Science Foundation Sri Lanka 35: 49-51.

43. Goshwami D, Mostafizur R, Abdul M, Saiful I (2013) In-vitro evaluation of anthelmintic activity of Lasiaspinosa leaves. International Journal of Current Pharmaceutical Research 5: 34-35

44. Gunathilake KDPP, Yalegama C, Kumara AAN (2009) Use of coconut flour as a source of protein and dietary fibre in wheat bread. Asian Journal of Food and Agro-Industry 2: 382-391

45. Hegenbart S (1992) Using fiber in food products. Journal of Food Science. 9 $15-18$

46. Hettiaratchi UP1, Ekanayake S, Welihinda J (2011) Sri Lankan rice mixed meals: effect on glycaemic index and contribution to daily dietary fibre requirement. Malays J Nutr 17: 97-104.

47. Industrial Lines for the production of dry baked goods (2013) WP IndustrialWP Bakery group.

48. Lattimer JM, Haub MD (2010) Effects of dietary fiber and its components on metabolic health. Nutrients 2: 1266-1289.

49. Jian L (2009) Total Anthocyanin Content in Blue Corn Cookies as affected by Ingredients and oven types. Journal of Food Science3: 17-80.

50. John RS, Jackie A (2013) Automated Determination of Total Fat, Saturated Fat Monounsaturated Fat and Trans Fat Content in Food Samples. Journal of Food Composition and Analysis 8: 251-267.

51. Khatkar (2003) Soft Wheat Products and Processes. Journal of cereal science 2: $87-117$.

52. Michaelsen KF, Hoppe C, Roos N, Kaestel P, Stougaard M, et al. (2009) Choice of foods and ingredients for moderately malnourished children 6 months to 5 years of age. Food Nutr Bull 30: S343-404.

53. Kotler P, Armstrong G (1997) Principle of Marketing (16th Edition). India

54. Garsetti M, Vinoy S, Lang V, Holt S, Loyer S, et al. (2005) The glycemic and insulinemic index of plain sweet biscuits: relationships to in vitro starch digestibility. J Am Coll Nutr 24: 441-447.

55. Majrcia AG, Esther H, Manuel G, Cristina MR (2012) Effect of different fibers on batter and gluten-free layer cake properties. Journal of Food Science and Technology 48: 209-214.

56. Marijana BS, Julianna FG, Aleksandra CM, Zita IS, Biljana SP, et al. (2011) Antioxidant activity of cookies supplemented with sugarbeet dietary fiber.
Journal of the science of Food and Agriculture 3: 151-157.

57. Metter TG (1998)Application Brochure.Switzerland:MCG MarconGriefensec

58. Mritunjay K, Prodyut M, Sudarshana B, Kabita M (2013) International Journal of Pharmacy and Pharmaceutical Sciences 5: 975-1491.

59. Nanasombat S, Teckchuen N (2009) Antimicrobial, antioxidant and anticance activities of Thai local vegetables. Journal of Medicinal Plants Research 3: 443449 .

60. Nest Ltd.Technical assistance (1998) Laboratory Instructions, Dry matter-oven Method. Singapore.

61. Nwosu, Justina N (2013) Production and Evaluation of Biscuits from Blends of Bambara Groundnut (Vignasubterranae) and Wheat (Triticumeastrum) Flours. International Journal of Food and Nutrition Science2: 2165-5308.

62. Pangborn SD (1984) Sensory evaluation properties. Journal of food science 60: 119-123.

63. Peter RW (1995) Classification of biscuit types and methods of production Journal of Food Science and Technology 2: 103-123.

64. Ranasinghe RAD (2003) Calibration and validation of Halogen Moisture analyzer to determine total solid content in coconut milk. Journal of Wayamba Sri Lanka 25: 120-156.

65. Jayawardena R, Byrne NM, Soares MJ, Katulanda P, Yadav B, et al. (2013) High dietary diversity is associated with obesity in Sri Lankan adults: an evaluation of three dietary scores. BMC Public Health 13: 314.

66. Schmidt DA, Dempsey JL, Kerley MS,Porton IJ (1995) Fiber in APE Diets. Canadian Journal of Diabetes 21: 235-255.

67. SLS standard for the biscuits (2010).

68. SLS specification for Sesame seeds Sri Lanka Standard (1977) VDC 665.337.4 Bureue of CSC.

69. Srivastava S, Genitha TR, Yadav V (2012) Preparation and Quality Evaluation of Flour and Biscuit from Sweet Potato. Journal of Food Process Technology 3: 192.

70. Sudha ML, Srivastava AK, Vetrimani R, Leelavathi K (2006) Fat replacement in soft dough biscuits: Its implications on dough rheology and biscuit quality. Indian journal of Food Technological 30: 102-132.

71. Yadav AK, Temjenmongla (2012) Efficacy of Lasiaspinosa leaf extract in treating mice infected with Trichinellaspiralis. Parasitol Res 110: 493-498.

72. Thongsombat W, Sirichote A, Chanthachum S (2007) The production of guava juice fortified with dietary fiber .Journal of Science and Technology 29: 187-196.

73. Tokunaga M, Takahashi T, Singh RB, Rupini D, Toda E, et al. (2012) Diet, Nutrients and Noncommunicable Diseases. The Open Nutraceuticals Journal 5: 146-159.

74. Watts BM, Limaki LE, Jeffery LG, Elias (1990) Basic sensory methods for food evaluation. The International Development Research Centre.

75. Wikramanayaka TW (1996) Food and Nutrition: Hector kobbekaduwa agrarian research and training institute, Wijeramamawata, Colombo. 